\title{
A197 MODULATION OF SUBCUTANEOUS ADIPOSE TISSUE ADIPOKINES BY TNF- $\alpha$ BLOCKADE THERAPY IN PATIENTS WITH INFLAMMATORY ARTHRITIDES
}

Ladislav Šenolt, ${ }^{1}$ Markéta Kuklová, ${ }^{1}$ Lenka Bošanská, ${ }^{2}$ Lucie Andrés Cerezo, ${ }^{1}$ Hana Hulejová, ${ }^{1}$ Maria Filková, ${ }^{1}$ Karel Pavelka, ${ }^{1}$ Martin Haluzík, ${ }^{2}$ Jiří Vencovský1 ${ }^{1}$ Institute of Rheumatology, Department of Experimental Rheumatology, 1st Faculty of Medicine, Charles University in Prague, Czech Republic; ${ }^{3} 3 \mathrm{rd}$ Department of Medicine, 1st Faculty of Medicine, Charles University and General University Hospital, Prague, Czech Republic

\subsection{6/ard.2010.149021.7}

Objective Increased adiposity has been recently shown to protect against radiographic progression in rheumatoid arthritis (RA). Moreover, low adiponectin serum levels were suggested as mechanistic link between high adiposity and decreased radiographic damage in RA. Therefore, the aim of this study was to examine the hypothesis that beneficial effect of tumour necrosis factor (TNF)- $\alpha$ blockade therapy may be associated with local changes of adipokines in subcutaneous adipose tissue.

Methods Samples of subcutaneous adipose tissue for protein analysis were obtained from the same abdominal region in patients with RA $(n=9)$ and ankylosing spondylitis $(n=4)$ prior to and 6 months after the commencement of etanercept. Commercial ELISA assays were used for detection of subcutaneous adipose tissue concentrations of TNF- $\alpha$, interleukin (IL)-1, IL-6 and adipokines leptin, adiponectin, resistin, visfatin, vaspin and omentin. Western blotting was used to confirm modulated levels of the protein(s).

Results Subcutaneous adipose tissue concentrations of IL-1, TNF- $\alpha$, leptin, resistin, visfatin, vaspin and omentin have not changed during the observation period. However, the levels of adiponectin and IL- 6 decreased significantly 6 months following initiation of etanercept therapy (from $35.65 \pm 16.45 \mu \mathrm{g} / \mathrm{ml}$ to $15.70 \pm 10.40 \mu \mathrm{g} / \mathrm{ml}(\mathrm{p}=0.003)$ and from $102.36 \pm 45.26 \mathrm{pg} / \mathrm{ml}$ to $79.66 \pm 31.92$ ( $\mathrm{p}=0.049$ ), respectively). This observation was confirmed by western blotting. None of the cytokines or adipokines was associated with serum C-reactive protein.

Conclusion Beneficial effect of TNF- $\alpha$ blockade therapy on structural joint damage in patients with inflammatory arthritides may be, at least in part, mediated through the decrease of subcutaneous adipose tissue adiponectin and IL-6. 